\title{
THE ISSUES OF COMBATING RELIGIOUS EXTREMISM AND TERRORISM IN ISLAMIC SOURCES
}

\author{
Abdumutal Zakurlaev \\ Assistant-Professor, Doctor of Legal Sciences, Islamic Scholar, Republic of Uzbekistan
}

Article DOI: https://doi.org/10.36713/epra3772

\begin{abstract}
The article reveals religious-legislative aspects of combating against religious extremism and terrorism. Also, several verses of Koran and hadithes, views of foreign specialists on terrorism, the comparative analysis of countering is given from historical and modern national legislative aspects.
\end{abstract}

KEY WORDS: extremism, terrorism, religion, Koran, United Nations, legislation, conservation.

\section{INTRODUCTION}

The issue of terrorism has been of great concern to the international community over the end, especially in the last decade of the 20th century all over the world. Terrorism has become a major problem for the United Nations, the Organization for Security and Co-operation in Europe, many regional, international, non-governmental and public organizations, legislation, executive and law enforcement agencies as well as special services. Therefore, the causes and roots of terrorism are being studied by political and legal scientists, Islamic scholars as well as representatives of other spheres.

Conservation and strengthening of the atmosphere of tolerance, respect and kindness among the existing nations and citizens in our country should be the priority tasks or us. It is known that freedom of conscience and religion, rights of representatives of different nationalities are guaranteed, and religious tolerance is being strengthened in our country. At present, more than 130 nationalities are living in our country in harmony, and 16 religious organizations are functioning freely.

\section{METHODS}

The further development of mutual friendship and harmony in our society, the provision of equal rights for all citizens, regardless of nationality, religion or belief, will be in the center of our attention. In Uzbekistan, distribution of extremist and radical ideas that arise disagreements among them is absolutely forbidden.

Today, the increasingly bloody conflicts and controversies, the threat of terrorism and extremism occurring in some parts of the world, require us to be constantly informed and vigilant [1].

In ancient sources, details of assassinations killing of geniuses and rulers, commiting some kind of actions under a threat or forcing to abandon the crown are clearly described. Most of them can, based on modern thinking, be classified as terrorism and extremism. As example, we can list the killing of prince Hurzod, who fought against the Arab invaders and the assassination of Mirzo Ulugbek, the ruler of Movarounnahr. Mirzo Ulugbek's death grounded a good reason for the Shaybanid dynasty to come to power. Such terrible events have left their bloody traces not only in the Movarounnahr, but also in the East and Europe, and unfortunately, they still continue to grow in different ways up to the present to win the state.

In the last few years, groups of disbelievers have emerged wearing the mask of Islam. They use religion to pursue conflicts among believers, break the peace of mind among people, exacerbate negative attitudes such as corruption in society, and the pursuit of vicious aims. They claim to be and declare themselves "saviors protecting Islam and Muslims", 


\section{EPRA International Journal of Research and Development (IJRD)}

Volume: 5 | Issue: 5 | May 2020

- Peer Reviewed Journal

however, they are being reasons for the bloodshed of innocent civilians. The worst is that they are giving (their own) commentaries and interpretation to the Qur'an and the Hadith, which are sacred for every Muslim, attempting to justify their actions and to disseminate controversies among Muslims.

The Islamic religion does not permit to do extremist or terrorist acts, in any of the harsh conditions. According to its teachings, bloodshed is a grave sin, regardless of whose blood it is. Here is a reference to the holy sources: "... that whoever kills a person - unless it is for murder or corruption on earth - it is as if he killed the whole of mankind; and whoever saves a person, it is as if he saved the whole of mankind."[2].

Muslims are commanded to observe the principles of fairness, justice, and humanity, even when fighting against the enemy. Being conceited, aggression, and violence are strongly condemned. For example: "Allah hates the transgressors (aggressive people)."[3].

The end of the 20th century and present day has occupied a special place in the history of mankind carrying gravest practices and theories such as terrorism, religious extremism, being extremely addicted in religion, and fanaticism. It is totally wrong to attach terrorism to a single nation or religion. Indeed, no religion or no nation can justify terrorism. The person, who commits this crime, no matter on whose behalf he commits, must be punished accordingly.

In this respect, we found it appropriate to word the opinions of Dr. Muhammad Abdulmunim Abdulholiq, director of general law at Shariat and Law faculty at Azhar University in Cairo, from his monograph "Terrorist Crimes: Religious and Legal Approach" on religious extremism and terrorism, fanaticism. He says: "... murders, shedding innocent blood, ignoring or insulting those who oppose them are not considered a crime by these groups. They hide in the darkness and get prepared to attack the society in which they themselves are brough up. This is because they have a wrong opinion that the present society lives in the period of pre-Islamic Jahiliyyah, and residers of this society follow the laws of the disbelievers, both the leaders and those who follow them are wrong, they claim that they do not need Europe's developed science and culture. According to their beliefs, this society is governed by the material world, which is fed by the material items, the evil, and the so-called lustful desires. This belief allows them to commit conspiracies, develop greediness, making hidden wrongful plans, betrayal, and mischief in different places of the world.

Fanaticism does not mean terrorism. The difference is that fanaticism only implies goals that contravene society's religious and moral beliefs and traditions, but are not part of a crime - that is, it does not violate the law. Because the law does not consider ideas and opinions a crime, unless they contradict certain criminal codes. The law does not impose any penalties on all moral conduct. Laws and morals are separated from each other and are incompatible with each other. Not all morally bad behaving can be punished by law. Fanaticism can be religious or criminal, depending on social, economic and political circumstances." [4, p.289].

Based on the above-quoted argument, we refer to some of the verses mentioned in the chapter on sectarianism that are considered sacred for all Muslims in order to look at the work of some current fanatics groups.

When we talk about the groups (sects) cited in the Holy Qur'an, there are several ayahs in which they are mentioned. "Whoever kills a believer deliberately, the penalty for him is Hell, where he will remain forever. And God will be angry with him, and will curse him, and will prepare for him a terrible punishment." (Surah al-Nisa 93).

This verse notes, first of all, in our opinion, a human must not intend to murder other human. No matter the circumstances, if one kills an innocent person, one shall be subject to inevitable eternal punishment in hell for what he did. Therefore, we see evidence that a person does not commit an act of intentional infliction on the sacred verse. Commenting on this verse, it is understood that the fundamental principle of the Republic of Uzbekistan is that the right to life, freedom and personal immunity are guaranteed in Article 24-25 of the Constitution (chapter on rights and liberties of individuals and citizens). And according to the Criminal Code, premeditated murder (intentional killing),

- shall be punished with imprisonment from ten to fifteen years.

Premeditated murder in aggravating circumstances, that is: a) (killing of) two or more persons; b) the person or his close relatives in connection with his official or civilian duty; c) in a manner dangerous to the lives of others; d) in the process of mass disorders; e) with severe cruelty; f) in the face of national or racial hatred; g) on the basis of religious affiliations; h) to conceal another crime or to facilitate its commission; i) by a group of persons or by an organized group member, or by the interests of that group

-shall be punished with imprisonment from fifteen to twenty five years in prison or with a life imprisosnment.

"But seek, with what God has given you, the Home of the Hereafter, and do not neglect your share of this world. And be charitable, as God has been charitable toyou. And do not seek corruption in the 


\section{EPRA International Journal of Research and Development (IJRD)}

Volume: 5 | Issue: 5 | May 2020

- Peer Reviewed Journal

land. God does not like the seekers of corruption." (Al-Qasas, 77)

In this verse, it is ordered for the person in the first place to aspire for perfection, at the same time, the spiritual and material wealth left by his honest work, and the well-being of his children should be his legacy. Together with this, it is noted that a person shall be sentenced up to 20 years of imprisonment providing he violates the rules specified in articles 156, 159 (making conspiracy), of the Criminal Code of the Republic of Uzbekistan or commits crimes against the state and society specified in articles 216 , 242, 244, and 246.

10. Among the people is he who says, "Wehave believed in God." Yet when he is harmed on God's account, he equates the people's persecution with God's retribution. And if help comes from your Lord, he says, "We were actually with you." Is not God aware of what is inside the hearts of the people? 12. Those who disbelieve say to those who believe, "Follow our way, and we will carry your sins." In no way can they carry any of their sins. They are liars.13. They will carry their own loads, and other loads with their own. And they will be questioned on the Day of Resurrection concerning what they used to fabricate. (Surah alAnkabut, 10: 12, 13).

If we look at these verses from a contemporary legal point of cview, it is impossible to deny that the fanaticists (actors), first of all, are convinced that they are "believing in Allah" in order to justify their actions, consisting of corruption, conspiracy, and aggression in our country. When they are brought to justice, they try to hide their illusions in the way of Allâh, but that they can never escape responsibility for their actions in the Hereafter.

"And He brought down from their strongholds those of the People of the Book who backed them, and He threw terror into their hearts. Some of them you killed, and others you took captive." (Al-Ahzab: 26). In this verse, (it is implied that) it is not a secret that the members of the corrupted organizations that violate the law as well as who helped them are subjected to prosecution by the law enforcement agencies on the basis of the current legislation (constitution, the law about freedom of conscience, criminal and administrative laws). This way, they would be searched, responsibility for their actions is inevitability for them. On the basis of court decision they would be subject to deprivation of liberty as a punishment and in some cases, they are liquidated in the crime scene.

"Those who harm the believing men and the believing women, for acts they did not commit, bear the burden of perjury and a flagrant sin" (Al-Ahzab, 58).
While the criminals are being held accountable for the crimes they committed, they are, with purpose of condemning the public, official imams and law enforcement officials, distributing various fisquies, as well as unjustified accusations such as the violation of human rights, freedom of conscience, and use of torture. It is evidenced that these slanders are indeed wrong, and those who arrange and support these slanderous cases will be brought to justice inevitably not only in in this world, but also will have to answer the questions hereafter.

"If the hypocrites, and those with sickness in their hearts, and the rumor-mongers in the City (Madinah), do not desist, we will incite you against them; then they will not be your neighbors there except for a short while" (Surah al-Ahzab, 60). "They are cursed; wherever they are found, they should be captured and killed outright." (Surah Al-Ahzab, 61). Despite the fact that this verse is directly reflects the prophetic period, these attempts continue in our present days as well. For example, fanatic corrupts, disseminators of various rumors will be denied by the publicity for their actions, and we can not stand side by side with them for the crimes they have committed and, according to the current legislation, they will be prosecuted.

Say: "You will not be asked about our misdeeds, nor will we be asked about what you do" (Surah Saba, 25). Every sane human being is aware of the essence of his actions. According to the guaranteed rights in our Constitution, the punishment will be provided by the court for each person's unlawful act committed. No one is allowed to be accused of unjustified accusations. The court will judge on the basis of the principles of justice, witness testimony and clear justified evidence. The validity of this judgment will be examined by supervisory procedures, by cassation and appellate procedures, by higher judicial authorities. In addition, no one (as well as the relatives) shall be liable (if they are not related to the offense) for the the offense committed by another person and shall be exempted from liability.

The above-mentioned thoughts have been legally grounded, but we think if we do not illustrate the mentioned opinions in the light of the religious thought of the scholars of this direction, we would be judging unfairly with regard to the above-mentioned sacred words. The condemnation of fanaticism and violence in sacred texts, fatwas and the works of leading scholars [5, p.96-99].

Concepts such as fanaticism, terrorism, and extremism are described as "corruption", "gulu going deep", "'unf - violence" in the language of the Qur'an and Hadith. The verses of the Qur'an and hadiths describe the cited widely used concepts as violence, aggression, corruption, over-reacting. 


\section{EPRA International Journal of Research and Development (IJRD)}

Volume: 5 | Issue: 5 | May 2020

- Peer Reviewed Journal

Thus, the Islamic teachings have firm definitions in this respect. Leaving behind the principle of moderate behavior in religion is referred to as the apostasy in religion.

According to Muslim (narrator), the Prophet (peace be upon him) said three times that "They who abandon the middle (moderate) line shall be destroyed."[6].

"Allah desires ease for you and does not desire difficulty."[7].

"Of course, religion is easy. Whoever makes the religion difficult (for others), religion will become difficult for him. Make it easy, make it close, and give good news."[8].

"Do not go deep in religion. Those who went deep before you were lost in the religion."[9].

"It is not permissible for a Muslim to frighten his brother"[10].

"Whosoever points on his brother with an ironlike item, the angels curse him. "[11].

In the days close to the Last Day, people with ignorant minds with new teeth (young people) will appear. They speak good words, read the Qur'an, but it (their reading) does not pass through their chests (that is, they just read, they do not comprehend). They go out of the religion just as if they were fired from the bow. Kill them wherever you see them. There is a reward on the Day of Resurrection for killing them.

Today, such concepts as violence and fanaticism are called terrorism and exstremism. International Islamic organizations describe this phrase and indicate that the corruptions mentioned in the Qur'an are in line with this notion.

The Makkan declaration of the Islamic jurisprudence council of the Islamic world association describes terrorism as follows:

"Terrorism is the enmity to the religion, soul, consciousness, property and honor of the individuals, groups or state. Its scope includes the intimidation, harassment, threat, unjust suicide, and extortion of property, intimidation on the roads, bullying, violence, and the implementation of criminal plan with single or collective threats. The purpose of these actions is to put fear, danger, intimidation among people, or putting their life, freedom, and property at risk. This also includes causing environmental degradation, putting private or public ownership, domestic and natural resources at risk. All of this is a sinful act on the earth and Allah has forbidden Muslims from doing this in the Qur'an: "Do not desire mischief in the land. Verily, Allâh likes not mischief."'[12].

According to the Egyptian Council for Islamic Studies, terrorism is "terrorizing innocent people, breaking down things that are necessary for their lives, and destroying their possessions, their freedoms, and the honor of humanity."

Yusuf Qarzavi says: Islam prohibits the use of violence against innocent people, their property and honor. The Prophet (peace be upon him) made the announcement in the Farewell Sermon that the soul, property and honor of the people are inviolable. This applies not only to Muslims but also to other people. There is no principle in Islam that "the purpose justifies the means".

Sheikh Tantawi says: Terrorism and religious extremism are the intentions to kill the soul and property of people.

"Turn away from making innovations in religion, turn back from deep going, abstain from an overstatement, and relate to the ancient religion."[13].

As can be seen from the foregoing evidence, Islamic sources attach importance not to violence and disorder but to humanity, ease, and convenience. It is clear that it is the responsibility of men and women whether to go on the wrong way in understanding the values of Islam.

Fanaticism, corruption is not an actual issue which has emerged today. This problem, its negative consequences has been largely focused on by the great historians by giving legal and fictitious views on them. Our great ancestor, Usturshani Muhammad ibn Mahmud from Jizzakh, in his book Fazil al-Fusul, written in $1228 \mathrm{AD}$ (Hijri 625), wrote extended ideas about the opponents (corrupted people) of the state and society.

The bogiys (corrupted people) is a group of people who oppose the rightful ruler.

When the Muslims are living peacefully and in tranquility under the reign of rightful ruler, those who have rebelled against (that rightful ruler) are the bogiys. In such circumstances, people should be on the king side and not help the corrupted individuals. This is because it is considered to be helping the oppression. They should not help those who oppose the king as well. It will be a form of resistance against the king. If the aggression of the corrupted people is not the result of opression, but because they believe that they are in the right way, and the Ruler is not, that is why they want to seize the government, then men must take every opportunity to help the king against such a gang. For such a category has been cursed by our Prophet Muhammad (peace be upon him). He said that fitnah (conspiracy) is something sleeping. Whoever wakes it up, may he be cursed by the God.

If the bogiys (corrupted people) are accomplice in groups, according to the Molikiy, the Shafi'î and the Hanbaliy Madhab scholars, they will not be killed but they will be called to repentance after being captured. If he does not repent, he will be 


\section{EPRA International Journal of Research and Development (IJRD)}

killed. Some say that they will not be killed, but their morals will be corrected.

Hasan Basriy says: "Every heart will be rusted like iron. It is the remembrance of Allah and His forgiveness which makes the rust go" $[14$, p.1314].

"Every new day the dawn says: "O son of Adam, I have rised again, I am the witness of what you have done today, and take advantage of me, for I will never return until the Day of Judgment'[15].

"I did not leave today's job for tomorrow. When it comes to softness, I showed politeness, I've taken strict measures when it's time to use stricktness. I have never hurried when there is no necessity and I have not delayed the urgent issues" $[16, p .8]$.

The President of our country Shavkat Mirziyoyev was right when he addressed the 72nd session of the United Nations General Assembly appealing to communicate the truly humanistic essence of Islam to a broad world community. "We cherish our sacred religion as the focus of the timehonored values. We strongly condemn and we will never reconcile with those who rank our great faith together with violence and bloodshed", the President noted. "Islam calls us to kindness and peace, preservation of a genuine human beginning", the Head of the state has added. The President of Uzbekistan addressed the session delegates with a proposal to adopt a special resolution of the General Assembly "Enlightenment and religious tolerance. The main goal of this document is to promote universal access to education, elimination of illiteracy and ignorance. This resolution is aimed at promoting tolerance and mutual respect, promoting religious freedom, protecting the rights of believers, and preventing discrimination against them."[17].

\section{CONCLUSION}

In conclusion, in view of these circumstances, all scholars of the Islamic world today consider it necessary that we need to intensify the efforts to safeguard the purity and originality of Islamic teachings and to further combat against the evil forces that are trying to distort its rules. And I believe that keeping peace and tranquility in our country is a must and duty for every one of us.

\section{REFERENCES}

1. Mirziyoyev Sh.M. We build a free and prosperous democratic state of Uzbekistan together. From the speech at the joint session of the Chambers of the Oliy Majlis on the occasion of the solemn ceremony of the appointment of the President of the Republic of Uzbekistan. Uzbekistan 2016.

2. Abdulaziz Mansur. Translation and interpretation of the Holy Quran. TIU publishing house printing association, 2004. Surah Al-
Ma'idah (32) (Hereafter, the Qur'an translation and interpretation of meanings).

3. Translation and interpretation of the Holy Quran. Surah al-Baqarah, 190.

4. Muhammad Abdulmun'im Abdulkholiq "Terrorist Crimes: Religious and Legal Approach". Cairo 1999.289 p.

5. A.Zakurlaev. From the book about religious extremist and terrorist organizations threatening the development of Uzbekistan, the dean of the Tashkent Islamic University, AbdullayevAbdullayev, commentary on religious tolerance. Tashkent, 2010, 96-99 p.

6. Muslim. Sahih.

7. Baqarah: 185.

8. Bukhariy. Sahih. Kitabul iyman. Muslim. Sahih. The book hypocricy.

9. Ahmad ibn Hanbal. Musnad.

10. Abu Dawood Sunan. Book of morality.

11. Muslim. Sahih. Kitabul birr.

12. The magazine Islamiz mind. № 437. April. 2002.

13. Ilomul muvaqqiyin. V. 4. $150 \mathrm{p}$.

14. Reported by Imam Bayhaqi. Calendar for 2018/2019, 13-14 p. Tashkent 2018.

15. Hasan Basriy, the same source.

16. The same source, $8 \mathrm{p}$.

17. Address of the President of the Republic of Uzbekistan Shavkat Mirziyoyev at the 72nd session of the United Nations General Assembly, September 19, 2017. 